\title{
The Effect of Management Accounting Systems and Enterprise Risk Management to Organizational Performance with a Competitive Advantage as an Intervening Variable
}

\author{
Asti Damayanti* Yvonne Augustine \\ Bussines and economics faculty, Trisakti University, Jl. Kyai Tapa No.1 Tomang, \\ Grogol petamburan, West Jakarta, 11440
}

\begin{abstract}
The purpose of this paper is to examine the effect of management accounting systems (MAS) and enterprise risk management (ERM) to organizational performance (OP) with a competitive advantage (CA) as an intervening variable. The research method involved administrating a questionnaire to all company in Jakarta. The respondents were all staff in the company with minimum education as a college with economic basic. The significant findings on the effect of ERM in OP, while MAS have not to effect to OP and CA cannot be mediating the correlation between ERM to OP and MAS to OP. The limitation of the study is used as a general research object to fulfill the questionnaire. Future studies could use more specific research object. The implication of this study is the regulating body could consider making a regulated to implementing ERM to all company not only financial institutions.
\end{abstract}

Keywords: Management Accounting Systems, Enterprise Risk Management, Competitive Advantage, and Organizational Performance.

DOI: $10.7176 / \mathrm{EJBM} / 11-12-07$

Publication date: April $30^{\text {th }} 2019$

\section{Introduction}

The rapid development of the business world, especially in Indonesia, requires every company in all sectors to have a competitive advantage in order to survive. Not just a competitive advantage, then the company must have a sustainable competitive advantage. In order to fulfill this, the Company as an organization must have various strategies. Forming a strategy or planning certainly requires reliable information, both information sourced from internal and external companies.

The Management Accounting System (MAS) is present as an answer to the data information needs. Management Accounting System is a system that produces output using certain inputs and processes them to achieve management goals. A process can be explained by activities such as collecting, measuring, storing, analyzing, reporting and managing information. While output can be in the form of special reports, product costs, customer costs, budgets, performance reports, and even personal communication. Management Accounting Systems are not bound by a formal criterion that explains the nature of input or process and output. The criteria are flexible and based on the objectives to be achieved. In its development, the management accounting system is no longer just a provider of internal information data but also external data according to company needs. The existence of a well designed and appropriate MAS will support managers to be more effective in decision making, thus helping organizations improve efficiency and remain competitive in an environment that is always challenging. This in itself will improve organizational performance (Chenhall, 2003; Ismail and Isa, 2011).

Enterprise Risk Management (ERM) is a process that involves the board of directors, management and members of the company, which are implemented in strategy settings in all parts of the company. ERM is designed to identify potential events that can affect the company, and manage risk to be at the level of risk that can be accepted by the company (risk appetite), to provide confidence in the achievement of the entity's objectives. (COSO, 2004; CIMA, 2008). ERM controls the risks faced by companies in an integrated and holistic manner. Failure to identify, assess, and manage risk can result in losses to stakeholders and shareholders. In addition, ERM can help companies achieve their main goals and create value through the implementation of ERM that is directly linked to the preparation of the company's strategy.

An organization develops a different strategy to improve its reputation and to reduce the risk. To do that, ERM implementation is very necessary for terms of strategy building (Yilmaz and Flouris, 2017). For decision making, planning, and organizational control systems, ERM is very important in an organization. In addition, ERM practices are not only important for financial performance but also increase the company's non-financial performance (Rasid et al. 2014). The top management team is responsible for organizational strategies, cost reduction, and long-term planning, and from this perspective, they need to be aware of ERM practices, which have a direct influence on the organization's strategic decision-making processes, costs, and activities (Meidell and Kaarbøe, 2017). To respond to unexpected challenges and losses, top management requires long-term planning, effective ERM strategies and practices (Krause and Tse, 2016) In short, a company carries out several practices for CA, even though ERM practices are used fundamentally for reducing various types of risks and facilitating 
companies to improve their sustainable CA (Elahi, 2013).

Porter (1980) states that a company can gain cost leadership competitive advantage by reducing operational costs, marketing, management, and material costs. Likewise, a company can obtain a competitive advantage based on differentiation by differentiating products and services from competitors. Both of Porter's strategies - cost leadership and differentiating based - have a significant influence on financial and non-financial performance. Empirical evidence shows that competitive strategies have a significant influence on company performance (Anwar et al. 2018).

In 2014, in the study of Rasid, Isa and Ismail, it was found that 1) the application of ERM requires the use of sophisticated MAS information, 2) ERM and MAS complement each other because they are an integral part of decision making, planning, and control in an organization. 3) ERM has an important role in improving nonfinancial performance. In 2018, in Yang, Ishtiaq and Anwar's research, it was found that 1) ERM practices had a significant influence on CA and SME performance. and 2) CA partially mediates the relationship between ERM Practice and company performance. 3. Financial literacy significantly mediates the relationship between ERM and CA. In 2018, in Nguyen's research, it was found that 1) Use of Accounting System Management which (in a broad scope, timely, aggregation and integration) is able to mediate the influence of market orientation on company performance 2) The level of accountant's participation in strategic decision making increases the positive relationship between MO and the use of MAS. In 2017, in Gnawali's research, it was found that Accounting System Management has a positive influence on company performance. Where MAS is a significant predictor of organizational performance. In 2015, in Rasid, Isa and Ismail's research, it was found that 1) Cost leadership and differentiation business strategies have a positive relationship to OP, but companies with a cost leadership business strategy are more suitable for implementing ERM compared to companies with differentiation strategies. 2) ERM implementation has a significant positive impact on the OP. 3) ERM is a partial mediator of the relationship between Cost Leadership and OP strategies but does not mediate the relationship between differentiation strategies and OP. The remainder of the paper is structured as follows, the relevant review, hypothesis development, research method, result and discussion, and conclusion.

\section{Literature Review}

\subsection{Management Accounting Systems}

Management accounting is the process of identifying and classifying accounting information for the benefit of economic decision making by internal parties. A complete and extensive definition of Management Accounting provided by Management Accountant Practice Committee is the process of identifying, measuring, collecting, analyzing, preparing, and communicating financial information used by management for planning, evaluation, control in an organization, and to ensure the correct use of resources -sources and accountability for these sources.

According to Chenhall and Morris (1986), there are four characteristics of Management Accounting System information which are as follows (in Muslichah, 2002):

a. Scope

In information systems, broad scope refers to the dimensions of focus, quantification, and time horizons. The traditional Management Accounting System provides information focused on events in the organization, which are quantified in monetary terms, and which relate to historical data. The broad scope of Management Accounting Systems that provide information relating to the external environment may be economic such as Gross National Product, total market sales, and market share of an industry, or may also be non-economic such as demographic factors, consumer tastes, competitor actions, and developments technology. The broad scope of Management Accounting Systems includes non-monetary measures of the characteristics of the external environment. In addition, the broad scope of the Management Accounting System will provide an estimate of the possibility of future events in probability measures.

b. Timelines

The ability of managers to respond quickly to an event is likely to be influenced by the timelines of the Management Accounting System. Timely information enhances Management Accounting System facilities to report the latest events and to provide quick feedback on decisions that have been made. So timely includes reporting frequency and reporting speed. Information timing refers to the distance between the request and the availability of information from the Management Accounting System to the requesting party.

c. Aggregation

The Management Accounting System provides information in various forms of aggregation which range from the provision of basic materials, unprocessed data to various aggregations based on a certain period of time or area, for example, the center of accountability or functional. Other types of aggregation refer to various formats that are consistent with formal decision models such as cash flow analysis discounted for capital budgets, simulations and linear programming for budget application, profit-volume-profit analysis, and inventory control models. In the latest development, information aggregation is a combination of functional and temporal information such as sales areas, cost centers, production and marketing departments, and information produced specifically for formal 
decision models.

d. Integration

The important aspect of controlling an organization is the coordination of various segments in suborganizations. Characteristics of Management Accounting Systems that help coordinate include target specifications that show the influence of segment interactions and information about the influence of decisions on the operations of all organizational subunits. Integrated information from the Management Accounting System can be used as a tool for coordination between segments of sub-units and between sub-units. The complexity and interdependence between sub-units will be reflected in integrated information from the Management Accounting System.

\subsection{Enterprise Risk Management}

Enterprise Risk Management (ERM) is a process that involves the board of directors, management and members of the company, which are implemented in strategy settings in all parts of the company. ERM is designed to identify potential events that can affect the company, and manage risk to be at the level of risk that can be accepted by the company (risk appetite), to provide confidence in the achievement of the entity's objectives. (COSO, 2004; CIMA, 2008). Risk management involves the process of identifying, evaluating and managing threatening events and as a process of internal communication, decision making, and internal monitoring of events that might occur. Enterprise risk management (ERM) adds a holistic perspective to the company's risk management process, where risk management is an integral part of enterprise governance and strategy (Bromiley et al. 2015).

\subsection{Competitive Advantage}

Porter (1998: 1), states that competitive advantage illustrates how companies can choose and implement generic strategies to achieve and maintain the competitive advantage. Value chains in companies in different industries, reflecting history, strategy, and success in implementing their strategies. One important difference is that the company's value chain may differ in its competitive scope from its competitors, a potential source of competitive advantage. The competitive scope has a large influence on competitive advantage because it forms the configuration and economy of the value chain.

According to Assuari (2011: 25), the concept developed by Michael Porter in business strategy decision making, known as generic strategy. This strategy describes the position of the strategy, which is designed to reduce the role of influence from opponents, which includes emphasizing the advantages of low or low costs, superior product differentiation, and focusing on low costs and focusing on the advantages of product differentiation.

According to Porter, quoted by Solihin (2012: 10), mentioning that there are three generic strategies in business units that can be the choice of companies from various industries to obtain a competitive advantage for the company's business. Named a generic strategy, because this strategy can be used by various companies from various types of industries. The three strategies are as follows:

a. Cost Leadership

This strategy is chosen by companies that have a broad competitive scope. In this strategy, the company strives to achieve the lowest costs compared to other companies in one industry.

The company will get enormous benefits in the presence of cost advantages. First, the company can determine a low selling price but still get an adequate margin compared to competitors who set the same price but have higher costs. Second, low costs can be an entry barrier for potential competitors who want to enter the same industry. According to David (2012: 276-277), to run a cost leadership strategy successfully, a company must ensure that the total cost across the chain is lower than the total cost of the competitor. The way to achieve this:

b. Differentiation (Differentiation)

This strategy was also chosen by companies that have a broad competitive scope. The company will choose several attributes that are considered by buyers in an industry as important attributes and the company strives to place its position uniquely in order to meet the needs of these buyers. From any source of differentiation made by the company, if the customer considers differentiation made by the company is something valuable, the customer will be willing to pay for the company's products at a higher price than the competitor's products.

Resource Based View (Barney, 1991) or Resource-Based Theory (Barney et al., 2011) is one of the most prominent theories in Indonesia in the scope of strategic management. This theory assumes that there is heterogeneity of resources within the company and explains the competitive advantage (sustainable) of a company through ownership of resources with certain characteristics. To achieve a sustainable competitive advantage, companies must have value $(\mathrm{V})$, rare $(\mathrm{R})$, cannot be replicated (I) and non-substitutable (N) resources (VRIN criteria). The purpose of ERM is to manage all risks simultaneously in a coordinated and strategic framework rather than managing risks separately (Nocco and Stulz, 2006).

\subsection{Organizational Performance}

Kaplan and Norton (1992) (in Haerudin, 2018) introduce four perspectives in the balanced scorecard to assess 
organizational performance that can be evaluated by management. The four perspectives consist of financial persepective, customer perspective, internal business process perspective and learning and growth persepective.

\section{Hypotheses development}

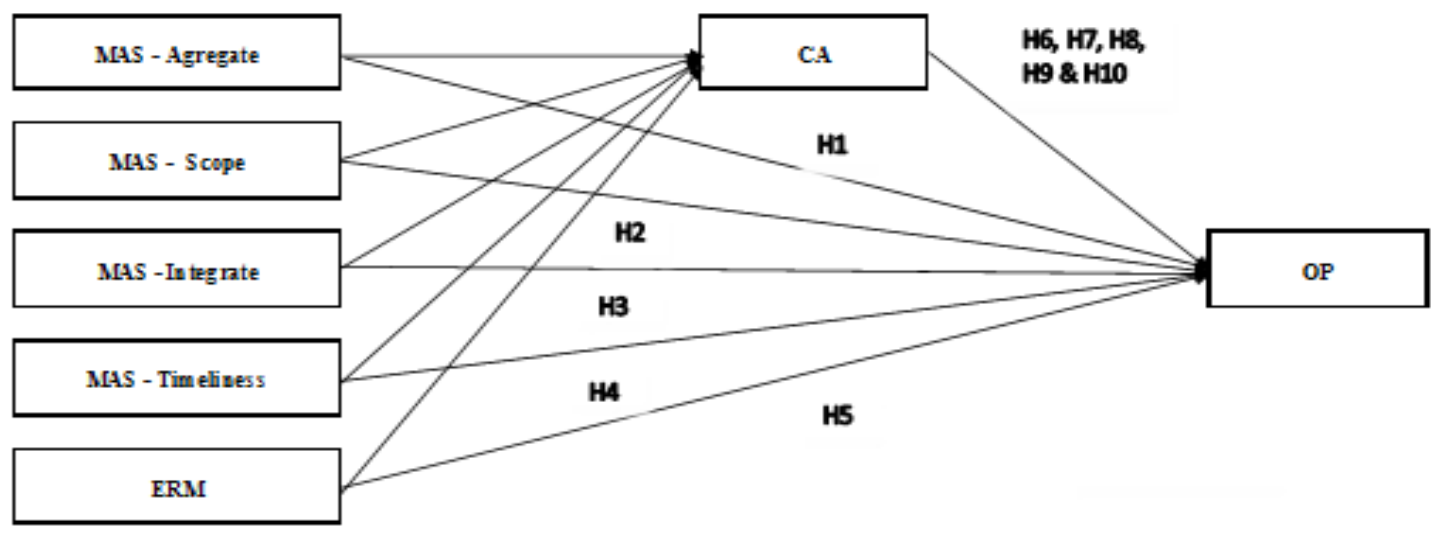

Figure 1. Research Model

Through the above explanation, it can be seen that the management accounting system and enterprise risk management have a positive influence on organizational performance. Likewise, after mediating competitive advantage with either cost leadership or differentiated based strategies, each has a positive influence on organizational performance. Therefore, based on the description above, the following development of the hypothesis in this study:

H1: Use of MAS - Aggregation has a positive effect on organizational performance.

H2: Use of MAS - Scope has a positive effect on organizational performance.

H3: Use of MAS - Integration has a positive effect on organizational performance.

H4: Use of MAS - Timeliness has a positive effect on organizational performance.

H5: ERM implementation has a positive effect on organizational performance.

H6a: Use of MAS - Aggregation mediated by CA - cost leadership has a positive effect on organizational performance.

H6b: Use of MAS - Aggregation mediated by CA - differentiation based has a positive effect on organizational performance.

H7a: Use of MAS - Scope mediated by CA - cost leadership has a positive effect on organizational performance.

H7b: Use of MAS - Scope mediated by CA - differentiation based has a positive effect on organizational performance.

H8a: Use of MAS - Integration mediated by CA - cost leadership has a positive effect on organizational performance.

H8b: Use of MAS - Integration mediated by CA - differentiation based has a positive effect on organizational performance.

H9a: Use of MAS - Accuracy mediated by CA - cost leadership has a positive effect on organizational performance.

H9b: Use of MAS - Accuracy mediated by CA - differentiation based has a positive effect on organizational performance.

H10a: The implementation of ERM mediated by CA - cost leadership has a positive effect on organizational performance.

H10b: The implementation of ERM mediated by CA - differentiation based has a positive effect on organizational performance.

\section{Research Method}

This study uses quantitative testing by examining the influence and relationship between research variables, namely management accounting systems, enterprise risk management, competitive advantage, and organizational performance. The research was conducted by distributing questionnaires to research subjects in all companies in Jakarta. The subjects in this study are all company employees who know the extent of the use of management accounting systems, implementation of ERM, competitive advantages that companies have and organizational performance both financially and non-financially. The object of this research is the opinions of company employees who know the extent of the use of management accounting systems, implementation of ERM, 
competitive advantages that the company has and the performance of the organization both financially and nonfinancially.

\subsection{Profile of respondent and firms}

The population in this study were all employees of both financial and non-financial companies, both private and state-owned companies. While the sample in this study were 55 employees. The instrument used in this study is a questionnaire given online to respondents. The total number of questionnaires distributed in this study was unlimited. From the link of the questionnaire distributed, 55 questionnaires were received again. Of the 55 received, 55 questionnaires can be processed. From responses were received, 26 of respondents was under 25 years old (47\%), 14 of respondents was under 30 years old (25\%) and the rest is over 30 years old (28\%). In total, $16 \%$ of the firms were public accountant companies, $16 \%$ of the firms were consultant companies, $9 \%$ of the firms were retail companies, $7 \%$ of the firms were manufacturing companies, $7 \%$ of the firms were construction companies, and the rest were logistic, fashion, regulator, mining, pharmacy, banking, insurance, telecommunication, shipping, etc. this indicates that respondents come from diverse companies.

\subsection{Measurement of variables}

Organizational Performance (OP)

The extent to which the organization has successfully achieved the planned target or target (Rasid, Isa and Ismail, 2014). Where the financial performance consists of financial performance and non-financial performance. Financial performance is measured using indicators of profits obtained by the company during the current year and the rate of return on investment (ROI) achieved by the company and Non-financial performance is measured using indicators of product/service quality provided to customers, service delivery, human resource development and company productivity in producing products or services.

\begin{tabular}{|l|l|}
\hline Variable & Indicator Instrument \\
\hline Organizational Performance & a. Non Financial Perform ance \\
& Quality \\
& Delivery of Service \\
& Personnel Developm ent \\
& Productivity \\
& b. Financial Perform ance \\
& Profit \\
& Return on Investm ent \\
\hline
\end{tabular}

Source: Rasid, Isa and Ismail, 2014

Management Accounting System (MAS)

The extent to which financial institutions use MAS information in terms of breadth of Scope, level of aggregation, integrative nature and timeliness (Rasid, Isa and Ismail, 2014). So that it can support management accountants to identify, collect, measure, analyze, prepare, interpret, and communicate information needed by management for decision making. The quality of accounting information produced will affect the quality of the management process.

\begin{tabular}{|l|l|}
\hline Variable & Indicator Instrument \\
\hline Management Accounting System & a. Aggregation \\
& On different sections \\
& Effect of events \\
Show the influence of events \\
Effect of different department \\
Decision models \\
What-if analysis \\
& b. Scope \\
& Future events \\
& Likelihood of future events \\
& Non-economic information \\
& External to the organization \\
& Non-financial-productivity \\
& Non-financial-market \\
& c. Timeliness \\
& Provided immediately \\
& Automatically \\
& Frequently \\
& Occurence of certain event \\
& d. Integration \\
& Precise targets of all activities \\
& Impact of different department \\
& Cost and price information \\
& Impact of Decisions \\
\hline
\end{tabular}

Source: Rasid, Isa and Ismail, 2014

Enterprise Risk Management (ERM)

The level of ERM implementation is based on the ERM framework proposed by the Committee of Sponsoring Organizations of the Treadway Commission (2004) (in Rasid, Isa and Ismail, 2014). Where risk management involves the process of identifying, assessing and managing threatening events and as a process of internal communication, decision making, and internal monitoring of events that might occur. 


\begin{tabular}{|l|l|}
\hline Variable & Indicator Inst rument \\
\hline Enterporise Risk Mconagement & a. Risk Managem ent Activities \\
& Regurarly monitored \\
& Control activities in the form of policies and procedures \\
& Risk irformation is captur ed \\
& Managem ent select risk response \\
& Regularly evahuted \\
& Effective communication \\
& Assessed potensial impact \\
& b. Perceived Risk \\
& Strategies aligned with risk attitude \\
& Internal erviromment determines how risk is view ed \\
& Risk and opportumities are distinguished \\
\hline
\end{tabular}

Source : Rasid, Isa and Ismail, 2014

Competitive Advantage (CA)

Stated that competitive advantage illustrates how companies can choose and apply generic strategies to achieve and maintain the competitive advantage (Porter (1980) in Soltanizadeh, Rasid, Golshan, and Ismail (2015)). The company's competitive advantage includes competitive strategies.

According to Soltanizadeh, Rasid, Golshan, and Ismail (2015) Indicator instrument of competitive advantage consist of:

1) Cost leadership.

2) Differentiated based.

Data analysis in this study using Partial Least Square (PLS) method. According to Kristaung and Augustine (2018) PLS can be used on each type of data scale (nominal, ordinal, interval, ratio) and the terms of a more flexible assumption. PLS is also used to measure the relationship of each indicator to its construct. In addition, in the PLS a bootstrapping test can be performed on the structural model which is the outer model and inner model. Because in this study using indicators to measure each construct, and also the measurement model is structural, it was decided to use PLS. According to Ghozali (2015) mentions PLS can be used for confirmation purposes, such as hypothesis testing and exploration objectives. In this case, the important thing that must be considered is the necessity of a theory that provides assumptions to describe the model, selection of variables, approach to analysis, and interpretation of results. This study aims to explain the relationship between extracts (MAS, ERM, CA and OP) and to understand the third definition of the extract.

\section{Results}

5.1 Measurement Model (Outer Model)

a. Validity and Reliability

\begin{tabular}{|l|c|c|c|}
\multicolumn{1}{|c|}{ Construct } & AVE & $\begin{array}{c}\text { Composite } \\
\text { Reliability }\end{array}$ & $\begin{array}{c}\text { Cronbachs } \\
\text { Alpha }\end{array}$ \\
\hline CA - Cost Leadership & 0.596 & 0,820 & 0.771 \\
\hline CA - Differentiate Based & 1.000 & 1,000 & 1.000 \\
\hline ERM & 0.599 & 0,952 & 0.945 \\
\hline MAS - scope & 0.701 & 0,921 & 0.892 \\
\hline MAS - timeliness & 0.702 & 0,904 & 0.861 \\
\hline MAS - integrated & 0.628 & 0,870 & 0.870 \\
\hline MAS - agregated & 0.745 & 0,946 & 0.803 \\
\hline OP & 0.610 & 0,932 & 0.919 \\
\hline
\end{tabular}

From the table above, it can be seen that the value of Composite reliability of each construct has a value of $>$ 0.8 and a check alpha of each construct $>0.5$, where the lowest value is 0.771 . So that it can be said that each construct has good reliability.

\subsection{Designing a Structural Model (Inner Model)}

\section{a. coefficient determination $\left(\mathrm{R}^{2}\right)$}

Variable ability The management accounting system both in aggregate, timeliness, Scope, and integration, as well as enterprise risk management and competitive advantage in explaining Organizational Performance, is $69.7 \%$. a value of $30.3 \%$ is influenced by other variables not tested in this study. While the ability of the variable management accounting system both in the aggregate, the timeliness, Scope, and integration as well as the company's risk management of competitive advantage - Cost Leadership is $40.4 \%$. a value of $59.6 \%$ is influenced by other variables not tested in this study. And the ability of the variable management accounting system both in the aggregate, the timeliness, scope, and integration and risk management of the company towards competitive advantage - differentiate based is $29.1 \%$. a value of $70.9 \%$ is influenced by other variables not tested in this study. 
b. Predictive Relevance (Q2)

Predictive Relevance $(\mathrm{Q} 2)$, which has a range of values $0<\mathrm{Q} 2>2$, where the closer to 1 the better. Based on the results of the calculation:

$$
\text { Q2 } \quad \begin{aligned}
&=1-(1-\mathrm{R} 12)(1-\mathrm{R} 22)(1-\mathrm{R} 32) \\
&=1-(1-0.697)(1-0,404)(1-0,291) \\
&=0.87196
\end{aligned}
$$

The Q2 value obtained is 0.87196 , where the value is close to 1 so the value can be said to be good.

c. Evaluation of Goodness of Fit

The goodness of Fit Index (GoF), the value obtained is getting closer to 1 the better. Based on the results of the calculation:

\begin{tabular}{|c|c|c|c|c|c|}
\hline & \begin{tabular}{|c|} 
Original \\
Sample \\
Es timate \\
\end{tabular} & Sample Mean & $\begin{array}{c}\text { Standar } \\
\text { De riation }\end{array}$ & T Statistics & PValue \\
\hline C.A - Cost Leades hip $>O P$ & 0,048 & 0,075 & 0129 & 0,373 & 0710 \\
\hline CA - Differentiale Based $>O P$ & 0,158 & 0,130 & 0131 & 1,204 & 0,229 \\
\hline ERM $>$ CA - Cost Leadership & $-0,050$ & 0,600 & 0291 & 0,206 & 0,838 \\
\hline ERM $\rightarrow$ C A - Dff Based & 0,183 & 0,179 & 0278 & 0,658 & 0,511 \\
\hline ERM $>$ OP & 0,925 & 0,907 & 0198 & 4,655 & 0,00 \\
\hline S.AM - agegate $>$ CA - Cost Leadership & 0,872 & 0,879 & 0282 & 3,094 & 0,002 \\
\hline S.AM - agregate $>$ CA - Diff Bxed & $-0,12$ & 0,087 & 0326 & 0,373 & 0,709 \\
\hline S.LM - agregate $>O P$ & -020 & 0,153 & 0.262 & 0,798 & 0.425 \\
\hline S.AM - scope-> CA - Cost Leades hip & -0354 & 0,316 & 0235 & 1,506 & Q,133 \\
\hline S.AM - scope - C CA - Diff Based & $0,3,2$ & 0,323 & 0218 & 1,650 & $Q 009$ \\
\hline S.LM - soope-> OP & $-0,100$ & 0,120 & 0.161 & 0,618 & 0,537 \\
\hline S.AM - itegratad - > CA - Cost Leades hip & 0,217 & 0,131 & 0267 & 0,812 & 0417 \\
\hline S.AM - ittegrated -> CA - Dfff Based & 0,044 & 0,061 & 0261 & 0,170 & 0,865 \\
\hline S.LM - itegrated $>O P$ & $-0,049$ & 0,078 & 0.185 & 0,264 & 0,792 \\
\hline S.AM - timeliness $>$ CA - Cost Leadership & -0311 & 0,241 & 0271 & 1,148 & 0,251 \\
\hline S.AM - timeliness - $>$ CA - DiffB ased & 0,106 & 0,124 & 0240 & 0,44 & 0,657 \\
\hline S.AM - tineliness $>\mathrm{OP}$ & 0,148 & 0,169 & 0.160 & 0,924 & 0356 \\
\hline
\end{tabular}

$$
\begin{array}{rlc}
\mathrm{GoF} & =\sqrt{0,697625 \times 0,464} \\
& = & 0,5689
\end{array}
$$

The GoF value obtained is 0.5689 , where the value is close to 1 so the value can be said to be good.

\subsection{Hypothesis Testing}

1. Testing of H1 Hypothesis

The negative original sample estimate values indicate that the management accounting system - aggregation has a negative effect on organization performance. Based on the regression results it can be concluded that the first hypothesis is rejected.

2. Testing Hypothesis $\mathrm{H} 2$

The negative original sample estimate values indicate that the management accounting system - the scope of negative influences is insignificant for organizational performance. Based on the regression results it can be concluded that the second hypothesis is rejected.

3. Testing of the H3 Hypothesis

The negative original sample estimate values indicate that the management accounting system - integration has a negative effect on organizational performance. Based on the regression results it can be concluded that the third hypothesis is rejected.

4. Testing of the H4 Hypothesis

The positive original sample estimate value indicates that the management accounting system - timeliness has a positive effect on the performance of the organization. Based on the regression results it can be concluded that the fourth hypothesis is rejected.

5. Testing of the H5 Hypothesis

The positive original sample estimate values indicate that enterprise risk management has a positive positive effect on organizational performance. Based on the regression results it can be concluded that the fifth hypothesis is accepted.

6. Testing of Hypothesis H6a

The positive original sample estimate value indicates that the management accounting system - aggregation has a significant positive effect on competitive advantage - cost leadership. While the positive original sample 
estimate indicates that competitive advantage - cost leadership has a positive and insignificant effect on organizational performance. Therefore it can be said that competitive advantage - cost leadership is not able to mediate the relationship between management accounting systems - aggregation with organizational performance. Based on the results of the regression it can be concluded that the sixth hypothesis is rejected.

7. Testing of Hypothesis H6b

The negative original sample estimate values indicate that the management accounting system - aggregation has no significant negative effect on competitive advantage - differentiate based. Whereas the original sample estimate value positively indicates that competitive advantage - differentiated based has no significant positive effect on organizational performance. Therefore it can be said that competitive advantage - differentiated based is not able to mediate the relationship between management accounting systems - aggregation with organizational performance. Based on the regression results it can be concluded that the eleventh hypothesis is rejected.

8. Testing of Hypothesis $\mathrm{H} 7 \mathrm{a}$

The negative original sample estimate values indicate that the management accounting system - the scope of negative effects is not significant for competitive advantage - cost leadership. While the positive original sample estimate indicates that competitive advantage - cost leadership has a positive and insignificant effect on organizational performance. Therefore it can be said that competitive advantage - cost leadership is not able to mediate the relationship between management accounting systems - Scope with organizational performance. Based on the results of the regression it can be concluded that the seventh hypothesis is rejected.

9. Testing of Hypothesis $\mathrm{H} 7 \mathrm{~b}$

The Positive original sample estimate values indicate that the management accounting system - Scope has no significant negative effect on competitive advantage - differentiate based. While the original sample est value Positive estimate indicates that the management accounting system - Scope has no significant negative effect on competitive advantage - differentiate based. Whereas the original sample estimate value positively indicates that competitive advantage - differentiated based has no significant positive effect on organizational performance. Therefore it can be said that competitive advantage - differentiate based is not able to mediate the relationship between management accounting systems - Scope with organizational performance. Based on the regression results it can be concluded that the twelfth hypothesis was rejected.

10. Testing of Hypothesis H8a

The positive original sample estimate value indicates that the management accounting system - integration has a positive and insignificant effect on competitive advantage - cost leadership. While the positive original sample estimate indicates that competitive advantage - cost leadership has a positive and insignificant effect on organizational performance. Therefore it can be said that competitive advantage - cost leadership is not able to mediate the relationship between management accounting systems - integration with organizational performance. Based on the regression results it can be concluded that the eighth hypothesis is rejected.

11. Testing of Hypothesis H8b

The positive original sample estimate value indicates that the management accounting system - integration has a positive but not significant effect on competitive advantage - differentiate based. Whereas the original sample estimate value positively indicates that competitive advantage - differentiated based has no significant positive effect on organizational performance. Therefore it can be said that competitive advantage - differentiate based is not able to mediate the relationship between management accounting systems - integration with organizational performance. Based on the regression results it can be concluded that the thirteenth hypothesis was rejected.

\section{Testing of Hypothesis H9a}

The negative original sample estimate values indicate that the management accounting system - timeliness has no significant negative effect on competitive advantage - cost leadership. While the positive original sample estimate indicates that competitive advantage - cost leadership has a positive and insignificant effect on organizational performance. Therefore it can be said that competitive advantage - cost leadership is not able to mediate the relationship between management accounting systems - timeliness with organizational performance. Based on the results of the regression it can be concluded that the ninth hypothesis is rejected.

13. Testing of Hypothesis H9b

The positive original sample estimate value indicates that the management accounting system - timeliness has no significant positive effect on competitive advantage - differentiate based. Whereas the original sample estimate value positively indicates that competitive advantage - differentiated based has no significant positive effect on organizational performance. Therefore it can be said that competitive advantage - differentiate based is not able to mediate the relationship between management accounting systems - timeliness with organizational performance. Based on the regression results it can be concluded that the fourteenth hypothesis is rejected.

14. Testing of Hypothesis H10a

The negative original sample estimate value indicates that enterprise risk management has a significant negative effect on competitive advantage - cost leadership. While the positive original sample estimate indicates that competitive advantage - cost leadership has a positive and insignificant effect on organizational performance. 
Therefore, it can be said that competitive advantage - cost leadership is not able to mediate the relationship between enterprise risk management and organizational performance. Based on the regression results it can be concluded that the tenth hypothesis is rejected.

15. Testing of Hypothesis $\mathrm{H} 10 \mathrm{~b}$

The negative original sample estimate value indicates that enterprise risk management has a negative effect not significant to competitive advantage - differentiate based. Whereas the original sample estimate value positively indicates that competitive advantage - differentiated based has no significant positive effect on organizational performance. Therefore it can be said that competitive advantage - differentiated based is not able to mediate the relationship between enterprise risk management and organizational performance. Based on the results of the regression it can be concluded that the fifteenth hypothesis was rejected.

\section{Discussion and conclusion}

1. Effect of using MAS - Aggregation, Scope, Integration and Timeliness of organizational performance

Based on the results of testing the first hypothesis it can be concluded that the management accounting system - aggregation, scope, integration and timeliness has a negative effect that is not significant on organizational performance. This is not in accordance with the hypothesis which states that the management accounting system - aggregation has a positive effect on organizational performance developed from the results of research by Achyut Gnawali, Ph.D., found that the management accounting system has a positive influence on company performance.

This is not in accordance with the results of Siti Zaleha Abdul Rasid's research, Che Ruhana Isa and Wan Kairuzzaman Wan Ismail, found that the relationship between ERM and management accounting systems aggregation had a positive influence on company performance.

2. Effect of ERM Implementation on organizational performance.

Based on the results of testing the fifth hypothesis it can be concluded that the company's risk management system has a significant positive effect on organizational performance. This is consistent with the hypothesis which states that the company's risk management system has a significant positive effect on organizational performance developed from the results of Siti Zaleha Abdul Rasid's research, Che Ruhana Isa and Wan Kairuzzaman Wan Ismail, finding that the relationship between ERM has a positive influence and an important role on company performance.

This is consistent with the results of Siti Zaleha Abdul Rasid's research, Che Ruhana Isa and Wan Kairuzzaman Wan Ismail, finding that ERM implementation has a significant positive impact on organizational performance.

3. Effects of the use of MAS - Aggregation, scope, integrationa and timeliness mediated by CA - cost leadership towards organizational performance.

Based on the results of testing the sixth, eight, ten, twelve hypothesis it can be concluded that competitive advantage - cost leadership is not able to mediate the relationship between management accounting systems aggregation, scope, integration and timeliness with organizational performance. This is not in accordance with the hypothesis that competitive advantage - cost leadership is not able to mediate the relationship between management accounting systems - aggregation, scope, integration and timeliness and organizational performance developed from the results of research by Songling Yang, Muhammad Ishtiaq, and Muhammad Anwar, found that the relationship between CA partial mediates the relationship between ERM Practice and company performance.

4. Effect of using MAS - Aggregation, scope, integrationa and timeliness mediated by CA - differentiation based on organizational performance.

Based on the results of the seventh, ninth, eleventh and thirteenth hypothesis testing it can be concluded that competitive advantage - cost leadership is not able to mediate the relationship between management accounting systems - aggregation, scope, integrationa and timeliness with organizational performance. This is not in accordance with the hypothesis that competitive advantage - cost leadership is not able to mediate the relationship between management accounting systems - aggregation, scope, integrationa and timeliness and organizational performance developed from the results of research by Songling Yang, Muhammad Ishtiaq, and Muhammad Anwar, found that the relationship between CA partial mediates the relationship between ERM Practice and company performance.

5. Effect of ERM implementation mediated by CA-cost leadership on organizational performance.

Based on the results of testing the tenth hypothesis it can be concluded that competitive advantage - cost leadership is not able to mediate the relationship between enterprise risk management and organizational performance. This is not in accordance with the hypothesis that competitive advantage - cost leadership is able to mediate the relationship between enterprise risk management and organizational performance developed from the results of Songling Yang's research, Muhammad Ishtiaq, and Muhammad Anwar, found that the relationship between CA partially mediates the relationship between Practice ERM and company performance.

6. Effect of ERM implementation mediated by CA - differentiation based on organizational performance.

Based on the results of the fifteenth hypothesis testing it can be concluded that competitive differentiation 
based is not able to mediate the relationship between enterprise risk management and organizational performance. This is not in accordance with the hypothesis that competitive advantage - differentiating based is able to mediate the relationship between enterprise risk management and organizational performance developed from the results of Songling Yang's research, Muhammad Ishtiaq, and Muhammad Anwar, finding that the relationship between CA partially mediates the relationship between Practice ERM and company performance.

In general, almost all independent variables do not have a significant effect on the dependent variable. Only enterprise risk management variables have a significant influence on organizational performance. This is caused by several factors, including:

1 . The object of research that is too diverse, where as many as $72 \%$ of respondents are aged $<30$ years and as many as $88 \%$ still have $<10$ years of work experience. Where in terms of experience and mindset of respondents, they are still considered lacking.

2. Respondents who came from companies with diverse industries, where the largest population worked in the Public Accounting Office as much as 16\%, consultants as much as $16 \%$, finance as much as $16 \%$, retail as much as $9 \%$ and other companies. Companies where working respondents still have a minimum in terms of systems and technology, so that when filling in the management accounting system questionnaire is still not right. And cause the results of processing data that are less significant.

3. The respondent's understanding is lacking in the statements contained in the questionnaire so that they tend to be accurate and not appropriate.

Based on Resource-Based View (Barney, 1991) or Resource-Based Theory (Barney et al., 2011) is a source of heterogeneity of resources within a company and explains the competitive advantage (managed) of a company through resources with various sources. In this case, competitive advantage can be realized with certain characteristics on resources, this criterion has a value (V), rare (R), inimitable (I) and resources cannot be substituted (N) (VRIN criteria). In this study companies where respondents work on average have not prioritized competitive advantage in companies in achieving company goals. One of them is that there is no adequate management accounting system, besides, only 3 companies have ERM divisions and/or CRO. Meanwhile, to gain a competitive advantage, there needs to be an adequate MAS and risk management analysis by the ERM and/or CRO division.

\section{Conclusion and limitation}

This study provides empirical evidence regarding the effect of management accounting systems, enterprise risk management on organizational performance with a competitive advantage as an intervening variable. The results of the study indicate that enterprise risk management has a significant positive effect on organizational performance. This is in accordance with the explanation of COSO, 2004 in CIMA, 2008. Where ERM is designed to identify potential events that can affect the company, and manage risk so that it is at the level of risk that can be accepted by the company (risk appetite), to provide confidence in achieving entity goals. Where the statement means through good ERM, organizational goals can be realized and able to improve organizational performance.

The limitations of the study are the parts that reveal the weaknesses of research, which might influence the results of the study. For example, weaknesses in the determination/selection of samples, research settings, use of research variables, or statistical testing assumptions that should be met.

The researcher has tried to design and develop this research in such a way, but because of the limited time so that there are still some limitations in this study, including:

1. The object of research is still general, both in terms of population, sample, and respondent. So that the results of the study are almost entirely insignificant.

2. Language in the questionnaire that still needs to be simplified, making it easier for respondents to understand. Because there are still many questions from respondents regarding the statements in the questionnaire which are considered layman or difficult to understand.

3. Statements on questionnaires that still need to be developed and adapted to the latest developments in science.

Implication and Suggestion

The results of this study indicate the influence of the company's risk management system on organizational performance. This shows that Enterprise risk management (ERM) is an important aspect of organizations and companies. In this case to improve the performance of an organization or company. In the various objects of research, ERM is able to show its influence in improving organizational performance. This application might be very influential when applied to financial institutions such as banking and insurance. Where business in financial institutions is a risky business.

It is better for management or practitioners to pay more attention to implementing ERM in the organization or company where they take shelter. Including giving socialization to all levels of the company community, not limited to top management only. But starting with top management and socializing to all subordinates (Top Down).

For further research, the following things can be taken into consideration, namely: 
1. Future research is expected to conduct research at companies that already have a CRO - Chief Risk Officer, generally a financial institution.

2. For variables that do not have a significant effect, can be reviewed whether it is still feasible to be tested again or can be replaced with other variables.

3. For questionnaires, you should pay attention to the respondents who are targeted and adjust the language used in the questionnaire so that it is easier to understand. Because this will greatly affect the results of the study.

4. Consider respondents, the cost and time of completion of research so that the research can be completed on time and on target.

5. The researcher can add statements to the questionnaire to the ERM variable according to the COSO criteria (2017).

\section{References}

Anwar, Muhammad, Sher Khan Zaman, and Najeeb Ullah Khan. (2018). Intellectual Capital, Entrepreneurial Strategy and New Venture Performance: Mediating Role of Competitive Advantage. Business Economic Review 10: 63-94.

Anthony, Robert N. \& Vijay Govindarajan. (2000). Management Control System. 8th Edition. Mc Graw Hill.

Assuari, Sofjan. (2011). Strategic Management, Sustainable Competitive Advantage. Indonesia, Jakarta.

Barney, J. (1991). Firm resources and sustained competitive advantage. Journal of Management, Vol. 17 No. 1 , pp. 99-120.

Barney, J. (2001). The resource-based view of the firm: ten years after 1991. Journal of Management, Vol. 27 No. 6, pp. 625-641.

Barney, J.B., Ketchen, D.J. and Wright, M. (2011). The future of resource-based theory: revitalization or decline?. Journal of Management, Vol. 37 No. 5, pp. 1299-1315.

Bromiley, P., McShane, M., Nair, A. and Rustambekov, E. (2015). Enterprise risk management: review, critique, and research directions. Long Range Planning, Vol. 48 No. 4, pp. 265-276.

Chenhall, R.H. (2003). Management control systems design within its organizational context: findings from contingency-based research and directions for the future, Accounting, Organizations and Society, Vol. 28 Nos 2/3, pp. 127-168.

Bockhodlt. (1998). Accounting Information System. Second Edition. McGraw Hill. New Delhi.

Chennhal, R.H. dan Morris. (1986). The Impact of structure, environment, and interdependence on the perceived usefulness of management accounting system. The accounting review. Vol. 61.No.1.

CIMA.(2008). Enterprise Risk Management, Topic Gateway Series No.49. The Chartered Institute of Management Accountants. London, United Kingdom.

COSO.(2017). Enterprise Risk Management, Integrating with strategy and performance. Executive Summary. Committee of Sponsoring Organizations of Treadway Commission.

David, R Fred. (2012). Strategic Management Concepts \& Cases. Pearson Academic; 14th edition

Elahi, Ehsan. (2013). Risk management: the next source of competitive advantage. Foresight 15: 117-31.

Garisson, Walter G. (2004). Managerial Accounting. Fifth Edition. Prentice Hall. New Jersey.

Gates, Stephen, and Christhope Germain. (2010). Integrating sustainability measures into strategic performance measurement systems. Management Accounting Quarterly 11 (3): 1-7.

Ghozali, Imam dan Hengky Latan (2015). Partial Least Squares, Konsep, Teknik dan aplikasi menggunakan program SmartPLS 3.0, untuk penelitian empiris. Semarang: Badan Penerbit Universitas Diponegoro

Gnawali, Achyut, Ph.D. (2017). Management Accounting Systems and Organizational Performance of Nepal Commercial Banks. The Journal of Nepalese Bussines Studies Vol X No.1.

Haerudin, M. Ikhwan Maulana. (2018). Pengukuran Kinerja Perusahaan dengan menggunakan Balanced Scorecard pada PT. Pegadaian (Persero) cabang Talasalapang di Kota Makassar. Jurnal Aplikasi Manajemen, Ekonomi dan Bisnis Vol.2 No. 2.

Hansen, Don R \& Marianne Mowen. (1997). Management Accounting. Fourth Edition. John Wiley \& Sons. New York.

Horngren, Charles T, et.al. (2006). Cost Accounting: A Managerial Emphasis. Fifth Edition. Pearson International Edition. New Jersey.

Ismail Solihin. (2012). Manajemen Stratejik. Jakarta : Arlangga.

Krause, Timothy A, and Yiuman Tse. (2016). Risk management and firm value: recent theory and evidence. International Journal of Accounting and Information Management 24: 56-81.

Kristaung, Robert, and Yvonne Augustine. (2018). Metodologi Penelitian Bisnis dan Akuntansi. Edisi Kedua. Dian Rakyat. Jakarta.

Lam, James. (2014). Enterprise Risk Management: From Incentives to Controls. Second Edition. John Wiley \& Sons, Inc. Hoboken, New Jersey. 
Langfield-smith, Kim and David Smith. (2003). Management control system and trust in outsourcing relationships. Management Accounting Research 14: 281-307.

Meidell, Anita, and Katarina Kaarbøe. (2017). How the enterprise risk management function influences decisionmaking in the organization-A field study of a large, global oil and gas company. The British Accounting Review 49: 39-55.

Muslichah. (2002). Pengaruh Tehnologi Informasi, Saling Ketergantungan, Karakteristik Sistem Akuntansi Manajemen Terhadap Kinerja Manajerial. Prosiding Simposium Nasional Akuntansi V. Hal 790 - 803 . FE Universitas Diponegoro. Semarang.

Nguyen, Nguyen Phong. (2018). Performance Implication of market orientation and use of management accounting systems. Journal of Asian Bussines and Economic Studies Vol 25 No.1 pp.33-49.

Nocco, B.W., Stulz, R.M. (2006). Enterprise risk management: theory and practice. Journal of Applied Enterprise Finance, Vol. 18 No. 4, pp. 8-20.

Porter, Michael E. (1980). Industry structure and competitive strategy: Keys to profitability. Financial Analysts Journal 36: 30-41.

Rasid, Siti Zaleha Abdul, Che Ruhana Isa, and Wan Khairuzzaman Wan Ismail. (2014). Management accounting systems, enterprise risk management and organizational performance in financial institutions. Asian Review of Accounting 22: 128-44.

Soltanizadeh, Sara, Siti Zaleha Abdul Rasid, Nargess Mottaghi Golshan, and Wan Khairuzzaman Wan Ismail. (2015). Bussines Strategy, enterprise risk management, and organizational performance. Management Research Review Vol 39 No.9 pp.1016-1033.

Yang, Songliyang, Muhammad Ishtiaq and Muhammad Anwar. (2018). Enterprise Risk Management Practices and Risk performance, the Mediating Role of Competitive Advantage and The Moderating Role of Financial Literacy. Journal of Risk and Financial Management Vol 11 No.35.

Yilmaz, Ayse Kucuk, and Triant Flouris. (2017). Enterprise risk management in terms of organizational culture and leadership and strategic management. In Enterprise Risk Management for International Business. Singapore: Springer, pp. 65-112. 